\title{
The Effect of Effleurage Massage to Pain Intensity of First Stage Labor in Inpartu Mothers at Linez Clinic of Gunungsitoli in 2018
}

\author{
*Hanna Sriyanti Saragih, Onnica Berthin Viany Zendrato \\ *Midwifery Department, Medan Health Polytechnic of Ministry of Health
}

\begin{abstract}
Pain in labor is a manifestation of the contraction (shortening) of the uterine muscle, and it was caused by stretching of the uterine and cervical segments as well as the presence of uterine muscle ischemia. According to WHO (World Health Organization) in 2015, it was estimated that every year 830 women died from complications of pregnancy and childbirth. One method that was very effective in dealing with pain is effleurage massage which was massage technique using the palms of the fingers with a circular motion pattern on the abdomen, waist or thighs. The purpose of this study was to determine the effect of effleurage massage on the intensity of first-stage labor pain in maternal mothers at Linez clinic of Gunungsitoli in 2018.

This type of research was guasy Experiment research design with non equivalent control group design. In this design, the grouping of sample members in experimental group and the control group was not random, using wilcoxon test. The population in this study were mothers in first pregnancy as many as 52 people, with a total sample of 20 experimental groups and 20 control groups. The data used were primary data using observation sheets.

From the research results, obtained $p$ value 0.0001 , it can be concluded that there was significant effect between experimental group and control group. It was hoped that midwives will update their midwifery service and practices such as participating in the latest midwifery training, so that they can increase their knowledge and apply it when conducting childbirth care as effort to reduce labor pain.
\end{abstract}

Keywords: Effluerage Massage, Pain Intensity of First Stage Labor

\section{PENDAHULUAN}

Persalinan adalah proses membuka dan menipisnya serviks dan janin turun ke dalam jalan lahir. Kelahiran adalah proses dimana janin dan ketuban didorong keluar melalui jalan lahir (Sarwono, 2014).

Rasa nyeri pada persalinan adalah manifestasi dari adanya kontraksi (pemendekan) otot rahim. Kontraksi inilah yang menimbulkan rasa sakit pada pinggang, daerah perut dan menjalar kearah paha. Nyeri persalinan disebabkan adanya regangan segmen bawah rahim dan servik serta adanya iskemia otot rahim. Puncak nyeri terjadi pada fase aktif di pembukaan 4-10 $\mathrm{cm}$, dan berlangsung sekitar 12-14 jam untuk primipara, dan 6-10 jam untuk multipara (Handayani, 2012).

Banyak metode yang ditawarkan untuk menurunkan nyeri pada persalinan, baik metode farmakologis (menggunakan obatobatan) maupun non farmakologis (secara tradisional).

Massage effleurage adalah teknik pijatan dengan menggunakan telapak jari tangan dengan pola gerakan melingkar pada abdomen, pinggang atau paha. Teknik ini bertujuan untuk dapat menurunkan tekanan darah, memperlambat denyut jantung, meningkatkan pernapasan dan merangsang produksi hormon endorphin 
yang menghilangkan rasa sakit secara alamiah (Maryunani, 2010).

Menurut WHO (World Health Organization), 2015 memperkirakan setiap tahun sejumlah 830 perempuan meninggal akibat komplikasi kehamilan dan kelahiran anak. Berdasarkan data diperoleh jumlah Angka Kematian Ibu dunia berjumlah 207 per 100.000 Kelahiran Hidup, dan jumlah AKI Indonesia sebanyak 359 per 100.000 kelahiran hidup.

Penelitian Nila Qurnasih (2017) yang bertujuan untuk mengevaluasi efektivitas massage effleurage terhadap penurunan intensitas nyeri persalinan yang dilakukan pada 36 orang ibu yang diberikan massage selama waktu $\quad 30$ menit dan 34 orang yang hanya diberikan perawatan standar selama 30 menit, dengan hasil analisis regresi logistik menunjukkan bahwa massage effleurage berpengaruh terhadap penurunan intensitas nyeri persalinan.

\section{METODE}

\section{Desain, Tempat, dan Waktu}

desain penelitian Quasy Experiment dengan rancangan Non Equivalent Control Group. Tempat penelitian ini adalah Klinik Linez Gunungsitoli. Waktu penelitian dilakukan pada bulan Mei hingga Juni 2018.

\section{Bahan dan Alat}

Bahan dan Alat yang digunakan adalah sebuah lembar observasi dan massage effleurage yang dilakukan kepada ibu inpartu.

\section{Prosedur Penelitian}

Meminta surat izin penelitian dari pengelola program studi D-IV Kebidanan Politeknik Kesehatan Kemenkes Medan sebagai bukti izin melakukan penelitian. Kemudian, mengajukan surat permohonan untuk melakukan penelitian di Klinik Linez Gunungsitoli, dan melakukan penelitian terhadap responden dengan memperkenalkan diri terlebih dahulu lalu menjelaskan tujuan apa yang akan saya lakukan, dan memberikan informed consent apabila responden setuju. Kemudian saya lakukan teknik massage effleurage sesuai Standar Operasional Prosedur dan mencatatnya di lembar observasi yang tersedia. Bersamaan dengan ini, saya; peneliti meminta bantuan terhadap teman sejawat saya yang berkerja di Klinik Linez Gunungsitoli sebagai enumerator, melakukan teknik ini saat ada ditemukan responden dengan kriteria inklusi yang diketahui. Setelah semua data terkumpul, peneliti melakukan pengolahan data dan analisis data.

\section{Pengolahan dan Analisis Data}

Analisa data untuk melihat pengaruh massage effleurage terhadap intensitas nyeri persalinan kala 1 di Klinik Linez Gunungsitoli Tahun 2018 dengan menggunakan uji Wilcoxon, yang merupakan uji alternatif dari uji pairing $t$ test atau $\mathrm{t}$ pairet apabila tidak memenuhi asumsi normalitas. Data dianalisis menggunakan software pengolah data SPSS.

\section{HASIL DAN PEMBAHASAN}

Rata-rata intensitas nyeri pada saat kelompok kontrol adalah 6,25 dengan standar deviasi 1,118, sedangkan pada kelompok eksperimen dengan rata-rata intensitas nyeri 2,00 dengan standar deviasi 0,649 . Hasil uji statistik didapatkan $p$ value 0,0001 maka dapat disimpulkan ada pengaruh yang signifikan antara kelompok kontrol dan kelompok eksperimen.

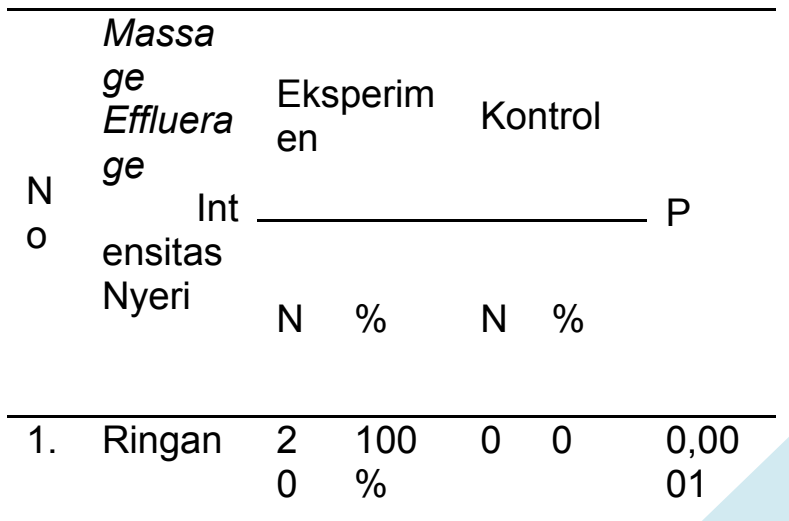




\begin{tabular}{lllll} 
2. Sedang & 0 & $0 \%$ & 1 & 55,0 \\
& & & 1 & \\
3. Berat & 0 & $0 \%$ & 9 & 45,0 \\
& & & & \\
\hline Total & $\mathbf{2}$ & $\mathbf{1 0 0}$ & $\mathbf{2}$ & $\mathbf{1 0 0}$ \\
& $\mathbf{0}$ & & $\mathbf{0}$ & $\%$
\end{tabular}

Hasil analisis menunjukkan bahwa data kelompok kontrol dan kelompok eksperimen adalah berturut-turut $p$ value 0,055 artinya $p$ value $>\alpha(\alpha=0,05)$ maka, data kelompok kontrol berdistribusi tidak normal dan data kelompok eksperimen $p$ value 0,297 (> 0,05 ) artinya tidak berdistribusi normal, maka data tersebut tidak berdistribusi normal dan dilanjutkan dengan analisis non-parametrik dengan menggunakan uji wilcoxon.

Rata-rata intensitas nyeri pada saat kelompok kontrol adalah 6,25 dengan standar deviasi 1,118, sedangkan pada kelompok eksperimen dengan rata-rata intensitas nyeri 2,00 dengan standar deviasi 0,649 . Hasil uji statistik didapatkan p value 0,0001 maka dapat disimpulkan ada pengaruh yang signifikan antara kelompok kontrol dan kelompok eksperimen.

Hal ini sejalan dengan penelitian Handayani, Winarni \& Sadiyanto (2013) mengukakan bahwa pengaruh metode massage effleurage terhadap pengurangan intensitas nyeri persalinan kala I fase aktif pada primipara memiliki nilai $p$ value $<\alpha(\alpha$ $=0,005)$ yakni $p$ value $=0,0001$ sehingga ada pengaruh metode massage effleurage terhadap pengurangan intensitas nyeri persalinan kala I pada primipara. Hasil penelitian ini sesuai dengan yang dikemukakan oleh Mander (2003) dan Tamsuri (2007) dengan gate control teori bahwa serabut nyeri membawa stimulus nyeri keotak lebih kecil dan perjalanan sensasinya lebih lambat dari pada serabut sentuhan yang luas dan sensasinya berjalan lebih cepat. Ketika sentuhan dan nyeri dirangsang bersama sensasi sentuhan berjalan keotak dan menutup pintu gerbang dalam otak dan terjadi pembatasan intensitas nyeri di otak.

Massage effleurage atau tindakan tindakan mengusap-usap abdomen secara perlahan, seirama dengan pernafasan saat kontraksi, yang digunakan untuk mengalihkan pikiran ibu, supaya ibu tidak memusatkan perhatiannya pada kontraksi (Maryunani, 2010). Sesuai dengan riset yang menunjukkan bahwa massage effleurage dapat mempengaruhi psikologis ibu inpartu dalam hal ini massage effleurage dapat membuat rileks, mengurangi ketegangan otot, dan menekan produksi hormon stress. Begitu ibu menjadi relaks dan tenang, otaknya akan kembali ke mode primitif dan oksitosin akan mengalir, sehingga akan segera dibanjiri dengan endorphin yang menghilangkan nyeri (Chapman, 2006). Maka dari itu, massage effleurage baik digunakan untuk ibu persalinan dikarenakan dapat menurunkan rasa nyeri yang dirasakan, hasil ini sama dengan keadaan pasien sebelum dilakukan massage effleurage memiliki rata-rata nyeri berat sebesar 7,27 dapat dikategorikan nyeri sakit pada tahap nyeri berat setelah dilakukan massage effleurage didapatkan rata-rata nyeri sebesar 2,15 dapat dikategorikan nyeri ringan. Ada penurunan yang sangat jauh setelah dilakukan massage effleurage. Melakukan massage effleurage ini pada perinsipnya rangsanga berupa usapan pada saraf yang berdiameter besar yang banyak pada kulit harus di lakukan pada awal rasa sakit atau sebelum implus rasa sakit yang di bawa oleh saraf yang berdiameter kecil untuk mencapai corteks serebral.

Rata-rata intensitas nyeri pada saat sebelum (tanpa dilakukan massage effluerage) pada kelompok kontrol adalah 7,35 dengan standar deviasi 0,489. Pada saat sesudah tanpa dilakukan massage effluerage adalah 6,25 dengan standar deviasi 1,118 . Hasil uji statistik didapatkan $p$ value 0,001 maka dapat disimpulkan ada pengaruh yang signifikan antara sebelum 
dan sesudah (tidak dilakukan massage effluerage). Rata-rata yang dirasakan tanpa dilakukan massage effluerage tidak memiliki perbedaan jauh antara sebelum dan sesudah, rata sakit yang terjadi dengan rentang ukur 7 dan 6 . Hal ini menunjukkan rentang nyeri berat dan nyeri sedang yang dirasakan responden. Akan tetapi, kelemahan penulis bahwasanya tidak dapat memperhatikan kelompok kontrol secara satu persatu disebabkan oleh keterbatasan waktu yang dimiliki. Penyebab penurunan nyeri ini bisa saja desebabkan dari beberapa teknik yang digunakan responden, misalnya dengan bantuan teknik relaksasi nafas atau teknik pijat lainnya. Karena dengan teknik relaksasi nafas maupun teknik pijat lainnya dapat mengurangi ketegangan, meningkatkan relaksasi fisik dan emosional dengan mengurangi kecemasan.

\section{KESIMPULAN}

Berdasarkan hasil penelitian mengenai "Pengaruh Massage Effluerage Terhdapa Intensitas Nyeri Persalinan Kala I Pada Ibu Inpartu Di Klinik Linez Gunungsitoli Tahun 2018" maka dapat diambil kesimpulan, yaitu : Pada kelompok eksperimen dengan diberikan massage effleurage terhadap intensitas nyeri persalinan kala I pada ibu inpartu di Klinik Linez Gunungsitoli tahun 2018 seluruh responden merasakan tingkat nyeri ringan yaitu sebanyak 20 responden (100\%). Pada kelompok kontrol tanpa diberikan massage effleurage terhadap intensitas nyeri persalinan kala I pada ibu inpartu di Klinik Linez Gunungsitoli tahun 2018 responden merasakan tingkat nyeri sedang yaitu sebanyak 11 responden $(55,0 \%)$ dan responden yang merasakan tingkat nyeri berat yaitu sebanyak 9 responden (45,0\%). Ada pengaruh signifikan antara kelompok eksperimen dengan dilakukan massage effluerage dengan kelompok kontrol tanpa dilakukan massage effleurage, dilihat dari hasil uji statistik didapatkan $p$ value 0,0001 .

\section{SARAN}

1. Bagi Tenaga Kesehatan

Diharapkan para bidan lebih up to date terhadap praktik pelayanan kebidanan, seperti ikut serta dalam pelatihan-pelatihan kebidanan yang terbaru, supaya dapat meningkatkan pengetahuan serta mengaplikasikannya saat melakukan asuhan persalinan sebagai upaya pengurangan rasa nyeri persalinan.

2. Bagi Institusi Pendidikan

Diharapkan dapat digunakan menjadi bahan masukan, sumber kepustakaan, dan menambah bahan referensi di Poltekkes Medan.

3. Bagi Peneliti Selanjutnya Diharapkan dalam peneliti selanjutnya dapat melakukan penelitian dengan jenis penelitian yang berbeda dan aspek yang lebih luas.

\section{DAFTAR PUSTAKA}

Chapman,V. 2006. TheMidwife's Labour and Birth Handbook. Blackwell Publishing, Oxford

Depkes RI. Profil Kesehatan Indonesia Tahun 2014, Jakarta: Departemen Kesehatan Republik Indonesia, 2014

Dinas Kesehatan Provinsi Sumatera Utara. Profil Kesehatan Provinsi Sumatera Utara Tahun 2013

Dwienda, Octa; Megasari, Miatu. dan Lusiana, Novita, 2015. Efektivitas Pijat dalam Mengurangi Nyeri Pada Kala I Persalnan. Jurnal kesehatan komunitas, Vol. 2 (6): 274-277

Handayani, Rohmi., Winarni dan Sadiyanto. 2013. Pengaruh Massage Effleurage Terhadap Pengurangan Intensitas Nyeri Persalinan Kala I Fase Pada Primipara di RSIA Bunda Arif Purwokerto Tahun 2011. Jurnal Kebidanan Vol 5 No (01). Akademi Kebidanan YLPP Purwokerto.

Handayani, Sri. 2016. Massage Effleurage Terhadap Tingkat Nyeri Kala 1 Fase Aktif. Stikes Yogyakarta. Jurnal Kesehatan (Samodra IImu). Vol 7 No (2). Yogyakarta.

Judha, Mohamad; Sudarti; Fauziah, Afroh. 2012. Teori Pengukuran Nyeri dan 
Nyeri Persalinan. Nuha Medika, Yogyakarta

Kementrian Kesehatan Republik Indonesia, Permenkes No. 97 Tahun 2014 Kementerian Kesehatan Republik Indonesia 2017. Profil Kesehatan Indonesia Tahun 2016

Mander, R.(2003). Nyeri persalinan. Jakarta: EGC.

Maryunani, Anik, 2010. Nyeri Dalam Persalinan (Teknik dan Cara Penanganannya). CV. Trans Info Media, Jakarta

M.Kep, S.Kep Solehati, Tetti; MNS, S.Kep Kosasih, Cecep Eli, 2017. Konsep dan Aplikasi Relaksasi dalam Keperawatan Maternitas. PT. Refika Aditama, Bandung

Notoadmojo, S, 2012. Metodologi Penelitian Kesehatan. Rineka Cipta, Jakarta

Pedoman Penyusunan Skripsi Prodi D-IV Kebidanan Medan, 2016

Peraturan Menteri Kesehatan Republik Indonesia Nomor 28 Tahun 2017 Tentang Izin dan Penyelenggaraan Praktik Bidan

Perry, GA. \& Petter, P. A. (2006). Buku Ajar Fundamental Keperawtan: Konsep, Proses, dan Praktek Edisi 4 Volume 2. Jakarta : EGC

Prawirohardjo, Sarwono, 2014. IImu Kebidanan. Bina Pustaka, Jakarta

Simkin, P., Walley, J., dan Keppler, A. (2008). Panduan Praktis Bagi Calon Ibu : Kehamilan dan Persalinan. Jakarta : PT. Bhuana IImu Populer

Sondakh, Jenny J. S,2013. Asuhan Kebidanan Persalinan dan Bayi Baru Lahir, Erlangga, Jakarta

Sugiyono, 2016. Metode Penelitian Kuantitatif, Kualitatif dan R\&D. Bandung, PT. Alfabet

Survey Demografi dan Kesehatan Indonesia (SDKI), 2012 Wahyuni, Sri, 2015. Pengaruh Massage Effluerage Terhadap Tingkat Nyeri Persalinan Pada Ibu Bersalin di RSU PKU Muhamadiyah Delanggu Klaten
2015, Jurnal Involusi Kebidanan, Vol. 5 (10): 44-52

Tamsuri, A. (2007). Konsep dan penatalasanaan nyeri. Jakarta: EGC

Utami, R.N., 2015. Perbedaan Efektivitas Lama Pemberian Rose Effleurage terhadap Intensitas Nyeri Kala I Fase Aktif pada Persalinan Normal Primigravida di Kota Semarang Tahun 2013. JURNAL KEBIDANAN, 2(4), pp.20-30

Wardani, Riska Aprilia \& Herlina. 2014. Efektivitas Massase Effleurage Dan Massase Counterpressure Terhadap Penurunan Nyeri Persalinan. Jurnal Keperawatan dan Kebidanan

Wardhani, Aisyah, 2017, Penerapan Effluerage Massage Untuk Mengurangi Nyeri Punggung Bawah Ibu Hamil Trimester III di BPM Yuspoenii,

http://elib.stikesmuhgombong.ac.id/3 65/1/AISYAH\%20SUKMA $\% 20 K U R N I A \% 20 W A R D H A N I$ \%20NIM.\%20B1401145.pdf, 16 April 2018 (22.05) WHO. World Health Statistics 2015: World Health Organization, 2015 